\title{
Farklı Kalınlıkta UYPB Laminelerin Eğilme Kapasitesine Katkısının İncelenmesi
}

\author{
Investigate the Influence of Different UHPC Laminates \\ Thickness to the Flexural Capacity
}

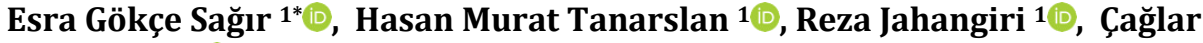 \\ Yalçınkaya 1 (i) \\ ${ }^{1}$ Dokuz Eylül Üniversitesi, Mühendislik Fakültesi, İnşaat Mühedisliği Bölümü, İzmir, TÜRKIYE \\ Sorumlu Yazar / Corresponding Author* ${ }^{*}$ esragokce.sagir@gmail.com \\ Geliş Tarihi / Received: 10.05.2019 Araștırma Makalesi/Research Article \\ Kabul Tarihi / Accepted: 29.07.2019 DOI:10.21205/deufmd.2019216329 \\ Atıfssekli/How to citeSAGIR, E.G., TANARSLAN, H.M.JAHANGIRI, R.,YALCINKAYA, C., (2019), Farklı Kalınlıkta UYPB Laminelerin Eğilme \\ Kapasitesine Katkısinin İncelenmesi, DEUFMD, 21(63), 1015-1026.
}

\section{Öz}

Çalışmada, ultra yüksek performanslı beton (UYPB) plakalarla güçlendirilmiş eğilme dayanımı yetersiz betonarme kirişlerin davranışı deneysel olarak incelenmiştir. Güçlendirme amacıyla kullanılacak plakaların imalatı için \%3 fiber hacmine sahip UYPB kullanılmıștır. Bir tanesi kontrol numunesi olmak üzere, kalınlık değişiminin eğilme davranışı üzerindeki etkilerini gözlemlemek amacıyla 3 farklı kalınlıkta UYPB plaka üretilmiş ( $30 \mathrm{~mm}, 50 \mathrm{~mm}$ ve $70 \mathrm{~mm}$ ) ve plakalar betonarme kirişlere uygulanmıștır. Kirişler, dört noktalı eğilme yükleri altında test edilmiştir. UYPB plaka ile güçlendirilmiş numunelerde yük taşıma kapasitesinde \%20 ila \%58 arasında değișen oranlarda artış elde edilmiştir.

Anahtar Kelimeler: Ultra Yüksek Performanslı Beton, Betonarme Kiriş, Güçlendirilmiş Kirişte Eğilme Davranışı

\section{Abstract}

The aim of this study is to investigate behavior of reinforced concrete beams with insufficient flexural strength which are reinforced by ultra high performance concrete (UHPC) were examined experimentally. UYPC with 3\% fiber volume was used for manufacturing laminates which will be used for reinforcing. UHPC having three different thickness $(30 \mathrm{~mm}, 50 \mathrm{~mm}$ and $70 \mathrm{~mm}$ ) where one of them will be control sample was used for observing effect of change in thickness over flexural behavior were manufactured and applied over reinforced concrete beams. RC Beams were tested under four -point bending loads. Increase in load carrying capacity varying with $20 \%-58 \%$ rates were obtained in samples which were reinforced with UHPC.

Keywords: Ultra high performance concrete, , reinforced concrete beam, flexural behavior in reinforced beam 


\section{Giriş}

Betonarme yapıların kullanım amaçlarının farklılașması ve yönetmeliklerin değișmesi ile yapılarda çeșitli nedenlerle ortaya çıan yetersizlikleri gidermek için kusurlu yapıların veya yapı elemanlarının güçlendirilmesi gerekmektedir. Betonarme yapıların güçlendirilmesinde; mantolama, epoksiyle yapıştırılmış çelik levhaların kullanımı, ardgerme ve karbon fiber polimer (CFRP) yapıștırma ile güçlendirme tercih edilen yöntemlerden bazılarıdır [1-11]. Ancak bu yöntemlerin; montaj zorluğu, uygulanan güçlendirme malzemelerin ağırlığı, uygulama esnasında hane halkının rahatsız edilmesi, korozyon riski ve yangına karşı dayanım eksikliği vb. dezavantajları bulunmaktadır.

Yapı malzemeleri teknolojisinde meydana gelen güncel gelişmeler, ultra yüksek performanslı beton (UYPB) gibi çeşitli çimento esaslı kompozitleri ortaya çlkarmıştır.

Ultra yüksek performanslı beton (UYPB); çimento, su, süperakıșkanlaștırıcı, silis dumanı ve çok ince kumdan oluşan bir karışımın sertleşmesiyle oluşan, bir matris içinde hacmen \%2-\%3'e varan oranda çelik tel içeren sünek bir betondur. Geleneksel betona göre eğilme yükleri altında yüksek enerji yutma kapasitesine ve dayanıma sahiptir. Bu yeni nesil çimento esaslı kompozitler; düşük geçirimlilik, geliştirilmiş durabilite, sınırlı rötre ve korozyon dayanımının arttırılması gibi diğer yüksek performans özelikleri de sağlamaktadır [12].

UYPB üretiminde, yoğun matriste, optimize edilmiș lif ve agrega fazları çok önemlidir. Bu nedenle optimize edilmesi gereken çelik lif dozajı, hem uygulama maliyeti hem de UYPB'nin mekanik performansını artırmak için anahtar parametre olarak kabul edilebilir. Yapılan araștırmalarda lif hacminin $\% 1$ ile $\% 5$ oranında değiștiği görülmektedir [13,31]. Lif hacmi \%5 oranına kadar arttırıldığında basınç dayanımı, gerilme ve elastisite modülünde artış yașanmasını sağlamıștır [13]. Çelik liflerin artırılması ile birlikte UYPB mekanik performansının büyük ölçüde iyileşmesine rağmen kendinden sıkıștırma ile ilgili eşik değerini karşılamak için karışıma yaklaşık \%2,5 oranında çelik mikro liflerin eklenebileceği ortaya çıkarılmıştır [14].

UYPB'nin yüksek performansını gözlemledikten sonra sadece mukavemeti değil aynı zamanda yüksek dayanıklılığı sayesinde modern yapıların inșaatında da yaygın kullanıma sahip olduğu anlaşılmıştır. Yapısal eleman olarak kullanımının yanında [15-20], güçlendirme veya onarım malzemesi olarak da kullanılması son zamanlarda araștırmacıların dikkatini çekmektedir [21-25]. Prem ve Murthy (2016) UYPB plaka kullanarak betonarme kirișlerin güçlendirilmesini incelemiştir. $\mathrm{Bu}$ çalışmada çeșitli donatı oranlarına sahip betonarme kirişler 10, 15 ve $20 \mathrm{~mm}$ kalınlıkta UYPB plakalar kullanılarak güçlendirilmiştir [21]. Araștırmacılar güçlendirilen kirișlerin eğilme yükleri altında monolitik davrandığını ve 10 mm plaka kullanımı durumunda başlangıçtaki eğilme kapasitelerini tekrar kazanabildiği göstermiștir. Herhangi bir ayrılma olmadığında kompozit kirişlerin monolitik olarak kırıldı ğı ve mukavemetin $\% 30 \quad$ oranında arttığ bildirilmiştir.

\section{Materyal ve Metot}

Çalıșma kapsamında eğilme dayanımı yetersiz betonarme kirișlere farklı kalınlıklarda yapıștırılan UYPB plakaların dayanım ve davranışta sağlayacağı iyileştirmeler mekanik deneylerle incelenmiștir.

Öncelikle çalıșmada kullanılacak UYPB'lerin karışım oranlarını belirlemek için malzeme deneyleri gerçekleștirilmiștir. İkinci așamada betonarme kirişlere uygulanacak boyutla üretilmiș UYPB plakalar test edilmiștir. Son olarakta kirişler UYPB plakalarla güçlendirilip test edilmiş, UYPB plakaların eğilme yetersizliğine sahip kirişlere dayanım ve davranış katkısı belirlenmiştir.

Deney elemanlarının üretilmesinde donatı, beton ve UYPB plaka kullanılmıştır. Donatı ve beton malzemelerinin karakteristik özellikleri, numuneler üzerinde laboratuvarda gerçekleştirilen testlerle belirlenmiștir. Deney elemanlarının üretilmesinde aynı özellikte beton ve aynı lottan temin edilmiş inşaat demiri kullanılmıștır.

\subsection{Ultra yüksek performanslı beton (UYPB)}

UYPB agrega iskeleti $0-0,4 \mathrm{~mm}$ ve $0,5-1 \mathrm{~mm}$ kuvars agregalardan olușmaktadır. Portlant çimentosu (CEM I 42,5 R) ve silika dumanı bağlayıcı malzeme olarak kullanılmıștır. $\mathrm{Bu}$ çalışmada yeni nesil polikarboksilat bazlı süper akışkanlaştırıcı kullanılmıştır. Lif olarak düz tip, $13 \mathrm{~mm}$ uzunlukta $0,20 \mathrm{~mm}$ çapında en boy oranı 0,65 olan pirinç kaplı çelik mikro lifler 
DEU FMD 21(63), 1015-1026, 2019

tercih edilmiștir. Liflerin doğrudan çekme dayanımı 2750 MPa'dır.

0.16 su/bağlayıcı oranına sahip UYPB tasarımları Tablo 1'de sunulmaktadır. Düșük su/bağlayıcı oranı ve lif takviyesiyle $200 \mathrm{MPa}$ basınç, $40 \mathrm{MPa}$ eğilme dayanımının yakalanması hedeflenmiştir. Bununla beraber aşırı düşük su/bağlayıcı oranlarında hidrate olmamıș tanecik sayısının arttığ Yüksek hacimli liflerde yeterli işlenebilirliliği sağlamak için UYPB karıșımları hacimce \%68 hamurdan oluşmaktadır. Homojen UYPB matrisi elde etmek için özel bir karıștırma prosedürü uygulanmıștır. Lif hacminin ișlenebilirlik üzerinde etkisini açıklığa kavuşturmak için akıșkanlaștırıcı dozajı sabit tutulmuștur. Hobart mikserde hazırlanan karışımlar 40×40×160 mm3 boyutlarındaki prizmatik kalıplara dökülmüștür. UYPB karıșımları üç katman halindeki kalıplar içerisine dökülerek her bir katman dıș vibrasyon esnasında çelik çubuk ile 25 vuruş kullanarak sıkıștırılmıștır.

Harç yayılma testi ASTM C1437 ile uygun olarak gerçekleştirilmiştir [26]. Karışımların mekanik performansı 28 günlük standart kürleme işleminden sonra değerlendirilmiştir.

\subsubsection{Yaş durum performası}

Ön hazırlı testleri çelik mikroliflerin işlenebilirlik düşürme etkisi ile başa çıkabilmek için \%68 hacimde yapıștırıcıya ihtiyaç duyulduğunu göstermiştir. Lif olmadan düzgün karışım elde etmek için yaklaşık $150 \mathrm{~mm}$ akış çapı amaçlanmış ve her bir fiber hacmi için sabit akışkanlaştırıcı dozajı kullanılmıştır. Sonuç olarak \%1 oranında çelik lif hacmi karıștırma esnasında kesme kuvvetini arttırarak işlenebilirliği iyileștirirken yüksek hacimlerde yayılma çapında dikkate değer azalmaya neden olmuştur (Şekil 1). Bu azalma liflerin ișlenebilirlik etkisine bağlı ilave iç sürtünmeye ve aşırı derecede düşük su/çimento oranına sahip karıșımların yüksek viskozitesine atfedilebilir. Her șeyden önce taze karıșımları vibrasyon ve el operasyonları aracılığıyla kalıpların içerisinde kolayca dökmek mümkündür. Ancak taze UYPB yüzeyini \%4 lif hacminde uygun sekilde bitirmek mümkün değildir.

\subsubsection{Mekanik performası}

0-0,4 $\mathrm{mm}$ ve 0,5-1 $\mathrm{mm}$ boyutlu agrega kullanılan lifsiz UYPB'nin ortalama basınç dayanımı 109 MPa elde edilmiştir. Ortalama basınç dayanımı $\% 1, \% 2, \% 3$ ve $\% 4$ çelik lif hacimlerinde sirasiyla 155, 185, 204 ve 214 MPa olarak elde edilmiștir.

Eğilme performansını değerlendirmek adına 6 $\mathrm{mm}$ sehime kadar çizilen, farklı lif hacimlerine sahip karışımların eğilme yükü - orta nokta sehimi eğrileri Șekil 2'de sunulmaktadır. Lif hacmi, karışımların davranışını dikkate değer șekilde etkilemiștir. Lifsiz UYPB'nin yük tașıma kapasitesi ve nihai sehim değerleri lifin dahil edilmesi sonucunda dikkate değer şekilde artmıștır. Eğilme yüklemesi altında tüm lif hacimleri ilk çatlaktan sonra daha yüksek bir yük seviyesine erișerek deformasyon sertleşmesine ve sünek davranışa neden olmuştur [26,27]. \%2 lif hacmine kadar maksimum yükler önemli oranda artmıștır.

Lifsiz karışım 16 MPa ortalama eğilme dayanımı sergilemiştir. \%1 ve \%2 lif hacminde bu değer sırasıyla \%56 ve \%163 oranında artarak 25 MPa ve 42 MPa'ya erişmiștir. Lif kullanımının $\% 3$ ve $\% 4$ olması durumunda basınç dayanımındaki eğilimin aksine eğilme dayanımlarında kayda değer bir artış oluşmamıştır. Lif hacmini arttırma hem eğilme hem de ilk çatlama dayanımını artırmıștır.

Sonuç olarak $40 \mathrm{MPa}$ eğilme ve $200 \mathrm{MPa}$ basınç dayanımı değerini yakalayan UYPB'yi elde edebilmek için \%3 çelik mikro lif kullanımının gerekliliği görülmüştür. Çalışmada güçlendirme amacıyla kullanılacak plakaların imalatı için \%3 lif hacmine sahip UYPB kullanılmıștır. 
DEU FMD 21(63), 1015-1026, 2019

Tablo 1. UYPB karıșım oranları.

\begin{tabular}{|c|c|c|c|c|c|}
\hline \multirow{2}{*}{ Bileşen (kg/m3) } & \multicolumn{5}{|c|}{ Karışımlarda lif oranları } \\
\hline & $0 \%$ & $1 \%$ & $2 \%$ & $3 \%$ & $4 \%$ \\
\hline $\mathrm{Su}$ & 200 & 200 & 200 & 200 & 200 \\
\hline Çimento & 1000 & 1000 & 1000 & 1000 & 1000 \\
\hline Silis dumanı & 250 & 250 & 250 & 250 & 250 \\
\hline $0,5-1 \mathrm{~mm}$ kuvars & 585 & 566 & 549 & 531 & 512 \\
\hline $0-0,4 \mathrm{~mm}$ kuvars & 251 & 243 & 235 & 227 & 220 \\
\hline Mikro çelik lif (13 mm) & - & 71,7 & 143,4 & 215,1 & 286,8 \\
\hline Akışkanlaştırıcı (ACE450) & 25 & 25 & 25 & 25 & 25 \\
\hline \multicolumn{6}{|c|}{ Tasarım Özellikleri } \\
\hline Agrega hacmi $(\%)^{*}$ & \multicolumn{5}{|c|}{32} \\
\hline Hamur hacmi (\%) & \multicolumn{5}{|c|}{68} \\
\hline Su /Çimento & \multicolumn{5}{|c|}{0,20} \\
\hline Su / Çimento** & \multicolumn{5}{|c|}{0,21} \\
\hline Su/Bağlayıcı & \multicolumn{5}{|c|}{0,16} \\
\hline Su/Bağlayıcı** & \multicolumn{5}{|c|}{0,17} \\
\hline
\end{tabular}

*Lifler agrega hacmine dahil edilmiştir. $\quad$ ** Katkıdan gelen su ile.



Şekil 1. Lif kullanımının işlenebilirliğe etkisi

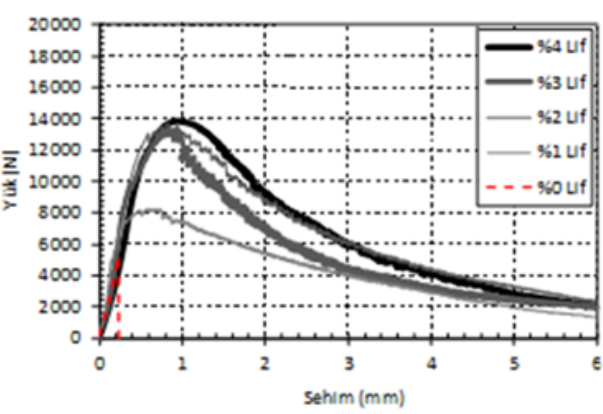

Şekil 2. Lif hacmine bağlı olarak eğilme yükü sehim eğrileri

\subsection{Deney elemanlarının özellikleri}

Eğilme yetersizliğine sahip deney elemanlar toplamda 4 adet özdeş $150 \times 250 \times 3200 \mathrm{~mm}$ boyutlarında ve tipik donatı yerleşimine sahip betonarme kirişlerdir.

Çalışmada UYPB plakaların eğilme dayanımına katkısının araştırılması hedeflendiği için deney elemanlarında buna uygun bir donatı düzeni belirlenmiştir. Donatı düzeni belirlenirken; güçlendirilmiş betonarme kiriş performansının yükleme çerçevesinin taşıma kapasitesini aşmaması ilkesi dikkate alınarak referans kirişin performansı belirlenmiştir. Kiriş tek doğrultuda iki eşit tekil yük altında test edileceği için kirişin çekme bölgesi her zaman kiriş alt yüzü olacaktır. Kirişin çekme bölgesinde 3 adet $12 \mathrm{~mm}$ çapında nervürlü donatı kullanılmıștır. Kirișin basınç bölgesinde ise 2 adet $10 \mathrm{~mm}$ çapında nervürlü donatı kullanılmıștır. Eğilme yetersizliğine sahip kirişte kesme kırılmasını engelleyecek bir kesme donatı düzeni oluşturulmuştur. $8 \mathrm{~mm}$ çapındaki kesme donatıları $125 \mathrm{~mm}$ aralıkla yerleştirilmiştir. Şekil 3'te kirişlerin donatı ayrıntılarını göstermektedir.

Mekanik özellikleri elde etmek için her bir çelik donatı türü gerilme altında test edilmiștir. Nervürlü donatıların akma dayanımı, kopma dayanımı ve elastisite modülü değerleri neredeyse aynıdır ve sırasıyla $470 \mathrm{MPa} 574$ $\mathrm{MPa}$ ve $205 \mathrm{GPa}$ değerindedir. 
Eğilme Yetersizliğine Sahip Deney Elemanı
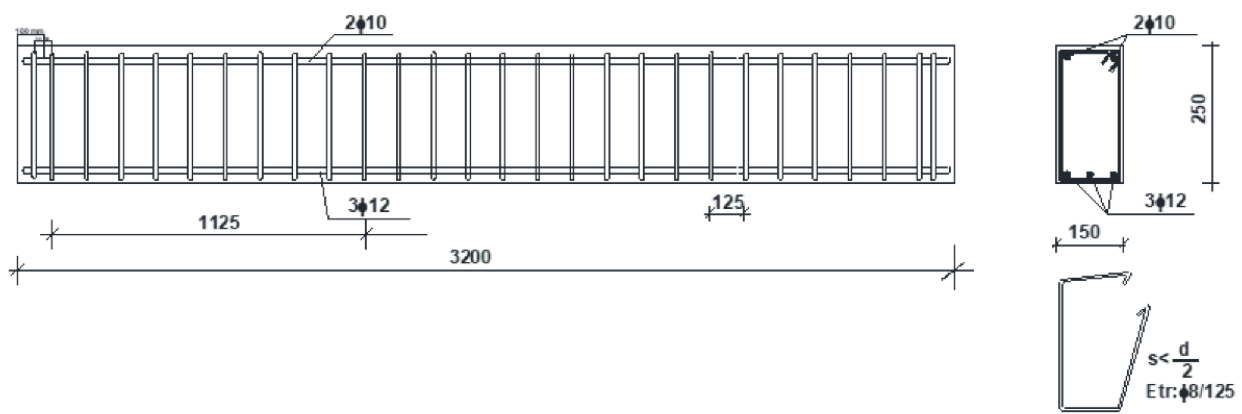

Şekil 3. Eğilme dayanımı yetersiz deney elemanı

Beton için kullanılan agrega büyüklüğü 20 mm'dir. Dört adet silindir numune dökülmüș ve beton basınç dayanımını belirlemek için kirişler 28 günlükken test edilmiștir. Betonun ortalama basınç dayanımı $204 \mathrm{MPa}$ 'dır.

Kalınlık değișimine bağlı olarak eğilme performansında oluşacak değişikliği gözlemlemek amacıyla 3 farklı kalınlıkta UYPB plaka üretimiştir. $30 \mathrm{~mm}, 50 \mathrm{~mm}$ ve $70 \mathrm{~mm}$ kalınlığa sahip plakalar incelenmiștir.

Plakaları üretebilmek için özel kalıplar kullanılmış, beton mikseri modifiye edilmiştir. Plaka üretimi için en önemli aşama yoğun lif oranına sahip yüksek dayanımlı betonu karıștırabilmektir. Çok düşük su/çimento oranlı kompozitleri karıștırmada, özellikle de yüksek döküm miktarlarında, geleneksel beton mikserleri işlev görememektedir. Yeterli kesme kuvvetini ve hızı uygulayabilen bir mikser gerekmektedir. $\mathrm{Bu}$ gereksinimleri sağlamak üzere laboratuvarda mevcut olan eski bir pan mikser modifiye edilmiştir. Pan mikserde, hazne kendi ekseninde dönmekteyken karıșmayı sağlayan düșeydeki bıçaklar sabit durmaktadır. Beton mikserine titreşimsiz, uygun devirli yeni bir motor takılmıştır. Karıştırıcı bıçakların yoğun kıvamlı karışıma uygun olması için yeri ve açısı güncellenmiștir. Daha sonra sistem hız kontrollü hale getirilmiştir. Pan mikserin modifiyesi sonucu elde edilen UYPB mikseri Şekil 4'te görülmektedir.

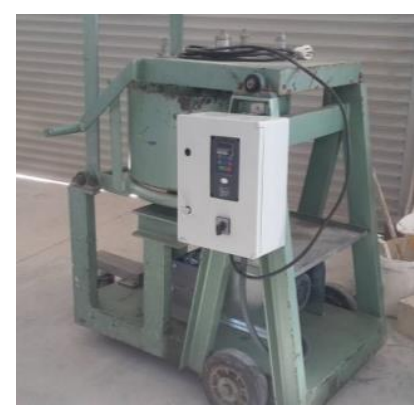

Şekil 4. UYPB mikseri

Malzemelerin karıştırma prosedürü Şekil 5 'te şematize edilmiştir. Plaka üretimine kullanılacak malzemeler hassas bir biçimde tartılarak başlanmıştır. Öncelikle bağlayıcı maddeler (çimento ve silis dumanı) 5 dakika boyunca düşük devirde karıștırılmıștır. Ardından karıșım suyu ve akıșkanlaștırıcıdan oluşan çözelti dönen miksere eklenmiştir. 10 dakika içinde akıcı hamur oluşturulmuş, kuvars agregaları bu akıcı hamura eklenmiştir. Çelik lifler 13 mm uzunluğa ve çok ince bir çapa sahip olduklarından stokta topaklanmış durumdadır. El yordamı ile çelik liflerin ayrıștırılıp, serpiștirilerek harca eklenmesi ve olușan UYPB karıșımının nihai homojenliğe ulaşması için 10 dakika daha karıştırma sürdürülmüştür. Karıșıma su katılmasından toplam 25 dakika sonra taze UYPB elde edilmiştir. 


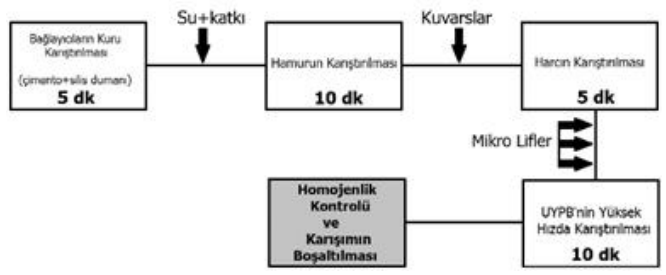

Şekil 5. UYPB karıştırma prosedürü

UYPB plakalar döküldükten sonra kalıptan sökülmesi için naylon örtülü numuneler laboratuvar ortamında 2 gün bekletilmiștir. Böylelikle ince elemanların $(30 \mathrm{~mm})$ sökümünde oluşabilecek sorunların önüne geçilmiştir. Kalıbından sökülen numuneler ıslak șilteler ve üzerine naylon örtü ile sarılmıștır. Laboratuvar sıcaklığında $\left(21 \pm 3{ }^{\circ} \mathrm{C}\right)$ neme doygun ortamda 28 gün kür edilen numuneler iki gün laboratuvar ortamında kurumaya alındıktan sonra UYPB plakalar betonarme kirişlere epoksi reçine ile yapıştırılmıştır.

Epoksinin elastisite modülü ve eğilmede ortalama 7 günlük çekme dayanımı sırasıyla $5000 \mathrm{~N} / \mathrm{mm}^{2}$ ve $33,3 \mathrm{~N} / \mathrm{mm}^{2}$ dir. Betonarme kiriș ile UYPB plakanın birbirlerine yapıșması için yüzey hazırlama işlemi yapılmıştır. İlk olarak betonarme kirişin yüzeyi mekanik așındırma ile pürüzlendirilmiș, basınçlı hava ile temizlenmiş ve astarlanmıștır. Yüzey istenen standartta olacak șekilde düzenlenince $2 \mathrm{~mm}$ kalınlıkta epoksi yapıștırıcı beton yüzeyine uygulanmiștır. Bundan sonra UYPB plaka basınçlı hava ile temizlenmiş ve epoksi kaplı kiriş yüzeyi üzerine yerleștirilmiştir. UYPB plakayı kirișe yapıștırmak için; kirișin uçlarına ve orta bölümüne yedi adet işkence kullanılmıștır. $\mathrm{Bu}$ ișkenceler sadece lokal yapıștırma sağlamaktadır. Bu nedenle kiriș ve UYPB plaka arasında uygun yapışma sağlayabilmek için ișkencelerin arasındaki her bir boşluğa 50 kg yük yerleștirilmiștir (Şekil 6). Sistem test edilmeden önce en az iki haftalık bir süreyle oda sıcaklığında kürlemeye bırakılmıştır. Kiriş altında çelik destekler koyarak benzer bir yapıștırma (bağlama sistemi) sahada uygulanabilir.

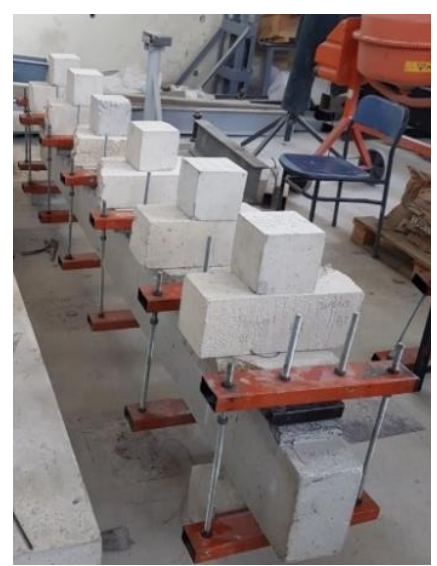

Şekil 6. UYPB plaka ile betonarme kirișin epoksi ile uygulanıp işsenceyle sıkıştırılması

Calıșmada 1 adet deney elemanı referans deney elemanı, diğer 3 adet deney elemanı ise farklı kalınlıkta UYPB plaka ile eğilme dayanımı artırılmıș kirișlerdir. Referans kiriș deney elemanı Kiriş-1, $30 \mathrm{~mm}$ UYPB plaka ile güçlendirilmiș deney eleman Kiriș-2, $50 \mathrm{~mm}$ UYPB plaka ile güçlendirilmiș deney eleman Kiriş-3 ve 70 mm UYPB plaka ile güçlendirilmiş deney eleman Kiriş-4 olarak isimlendirilmiștir.

\subsection{Deney düzeneği}

Kirișler dört noktalı eğilme yükleri altında test edilmiştir. Kirişlerin temiz açıklığı 3000 mm ve yükler arasındaki mesafe $300 \mathrm{~mm}$ 'dir. Tüm testlerde aynı yükleme hızını elde edebilmek için yükleme kontrol makinesi kullanılmıştır. Yükleme ișlemi numunelerde kırılma meydana gelene kadar uygulanmıştır. Üç adet birim deformasyon ölçer (LVDT) kirişin altına yerleştirilmiştir. Birim deformasyon ölçerlerden biri kirişin orta açıklı̆̆ına yerleştirilmiş ve diğer ikisi mesnet noktalarına karşılık gelen kısma yerleştirilmiştir. Deneysel düzeneğin şematik görününümü ve ölçüm cihazlarının yerleşimi Şekil 7'de sunulmaktadır. 


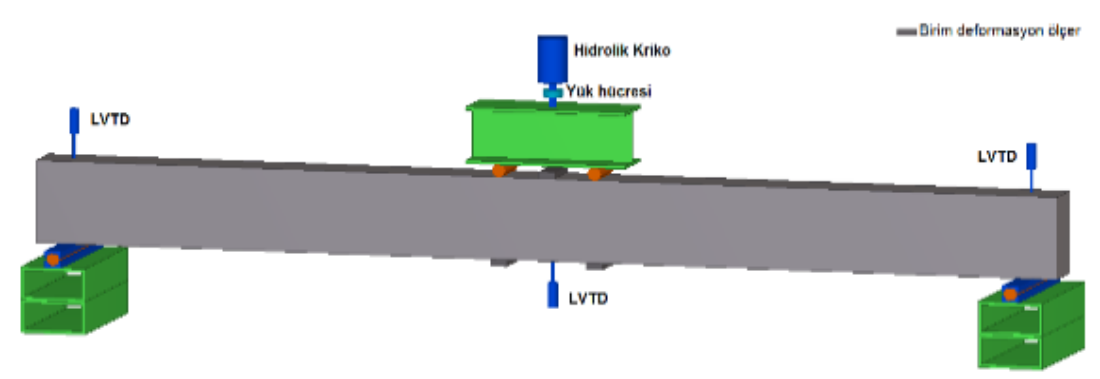

Şekil 7. Deney düzeneği

\section{Bulgular}

\subsection{Deney sonuçları}

Kiriş-1; çalışmanın eğilme referans numunesidir. Eleman eğilme dayanımı düşük olacak şekilde tasarlanmıştır. Artan yükler altında göçme gerçekleşinceye kadar test edilmiştir. İlk çatlak, kiriş orta bölgesinde kiriș eksenine dik ve ani olarak gelişim göstermiștir. $1072,74 \mathrm{~kg}$ yük ve $1,98 \mathrm{~mm}$ deplasman seviyesinde gerçekleşmiştir. Maksimum yükün yaklaşık \%25'i kadardır. Artan yükler altında kirişte eğilme çatlaklarının sayısında artış meydana gelmiştir. Yük-deplasman eğrisinden de anlașılacağı üzere buna bağlı olarak kirișin rijitliğinde azalma meydana gelmiştir. Yük $4406,19 \mathrm{~kg}$ ve $14,31 \mathrm{~mm}$ deplasman seviyesinde akmıştır. Numunenin nihai davranışını görmek için yüklemeye devam edilmiştir. $\mathrm{Bu}$ yük seviyesinden sonra kiriş yük tutamaz hale gelmiş ancak deplasman sünek davranışı gösterir şekilde artmaya devam etmiştir. Artan yükler altında kiriş orta bölgesinde gelișen çatlakların genişliklerinde artış gözlenmiştir. $\mathrm{Bu}$ bölgede ölçülen en büyük çatlak genişliği 0,1 mm seviyesine ulaşmıştır. Bu çatlaklara ek olarak kılcal düzeyde yeni çatlak oluşumları da kiriște gözlenmiștir. Deneye 75,53 mm deplasman seviyesine kadar devam edilmiștir. Bu deplasman seviyesinde basınç bölgesindeki betonun ezilmesi nedeniyle deneye son verilmiştir (Şekil. 8).

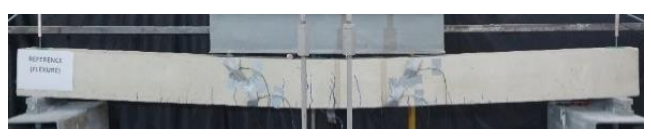

Şekil 8. Referans deney elemanı

Kiriş-2, $30 \mathrm{~mm}$ kalınlığa sahip UYPB plaka ile güçlendirilmiş test numunesidir. Deney elemanı artan yükler altında göçme gerçekleșinceye kadar test edilmiştir. Yük 2350,45 kg değerine ulaştığı zaman ilk eğilme çatlağı meydana gelmiştir. Maksimum yükün yaklaşık \%44'ü kadardır. Yük arttıkça yeni eğilme çatlakları meydana gelmiş ve kirişin orta kısmında yoğunlaşmıştır. 4327,67 kg seviyesinde oluşan çatlak ile birlikte yükte ani düşüş meydana gelmiş ancak UYPB plaka kirişin mevcut durumunu muhafaza etmesini sağlamıştır. Bu azalmadan sonra yük-deplasman eğrisinin eğiminin, çatlaktan önceki eğime göre arttığı görülmektedir. UYPB plakanın katkısıyla numune daha rijit davranmaya başlamıștır. Yük 5361,67 kg seviyelerinde akmaya başlamıştır. Numunenin nihai davranışını görmek için yüklemeye devam edilmiştir. 65,22 $\mathrm{mm}$ değerine kadar ulaştığı zaman numune basınç bölgesinde betonun ezilmesiyle deneye son verilmiștir (Șekil. 9).

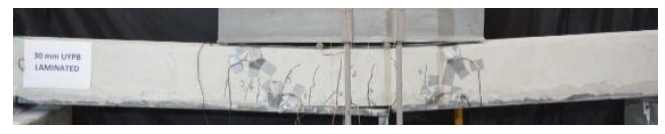

Şekil 9. $30 \mathrm{~mm}$ kalınlıklı UYPB ile güçlendirilmiş deney elemanı

Kiriş-3 $50 \mathrm{~mm}$ kalınlığa sahip UYPB ile güçlendirilmiș test numunesidir. Deney elemanı eğilme dayanımı düşük olacak şekilde tasarlanan kirişe $50 \mathrm{~mm}$ kalınlığa sahip UYPB plaka yapıștırılarak güçlendirilmiștir. Deney elemanında ilk çatlak maksimum dayanımın yaklaşık \%55'inde, kiriș orta bölgesinde, 3785,19 kg yük seviyesinde gerçekleşmiştir. Uygulanan yükün artmasıyla kiriş ortasında oluşan kılcal çatlakların sayısında artış gözlenmiştir. 4504,09 kg değerinde UYPB plakanın kirișten ayrılması esnasında dikkate değer sesler duyulmuştur. Ancak UYPB plaka iki parçaya ayrılana kadar plakanın yük taşıma kapasitesine katkısı devam etmiștir. $50 \mathrm{~mm}$ kalınlıklı UYPB plaka 6931,01 yük seviyesinden sonra kirişten ayrılmıştır. Bu yük seviyesinden sonra plaka ve kiriş iki ayrı eleman gibi davranış göstermeye başlamış ve yükdeplasman eğrisinde de görüldüğü üzere yük, referans kiriş seviyesine kadar düşmüştür. 
DEU FMD 21(63), 1015-1026, 2019

Kiriș, UYPB plakanın katkısını kaybettikten sonra 4710,07 kg yük seviyesine inmiştir. Epoksi ile yapıştırılan UYPB plaka kiriş yüzeyinden ayrılmamış ve 66,45 mm'ye kadar deplasman yapmaya devam etmiştir.

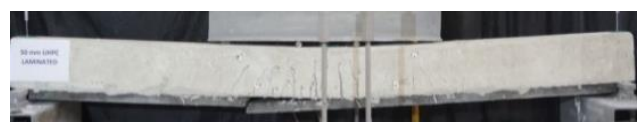

Şekil 10. 50 mm kalınlıklı UYPB ile güçlendirilmiş deney elemanı

Kiriş-4, 70 mm kalınlığa sahip UYPB ile güçlendirilmiş test numunesidir. Deney elemanı 70mm kalınlığa sahip UYPB plaka yapıștırılarak güçlendirilmiştir. Deney elemanında ilk eğilme çatlağı 5612,11 kg yük seviyesinde gelişmiştir. $\mathrm{Bu}$ yük seviyesinde orta mesnette $8,20 \mathrm{~mm}$ deplasman ölçülmüștür. $\mathrm{Bu}$ değer maksimum yükün yaklaşık \%95'i kadardır. Bu esnada liflerden ses gelmeye başladığı anda (lifler devereye girdiği anda) maksimım yük olan $5896,22 \mathrm{~kg}, 8,97 \mathrm{~mm}$ deplasman seviyesinde ani ve sesli olarak $70 \mathrm{~mm}$ kalınlıklı UYPB plaka kirişin arayüzünden ayrılmıştır. 11,21 mm deplasman ve $2723,71 \mathrm{~kg}$ seviyesinde diğer elemanlara göre gevrek davranış göstermiş ve göçme meydana gelmiştir.

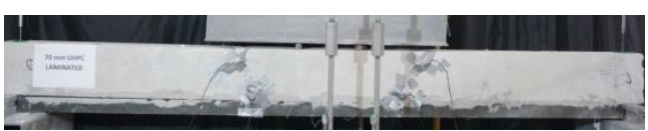

Şekil 11. 70 mm kalınlıklı UYPB ile güçlendirilmiş betonarme kiriș

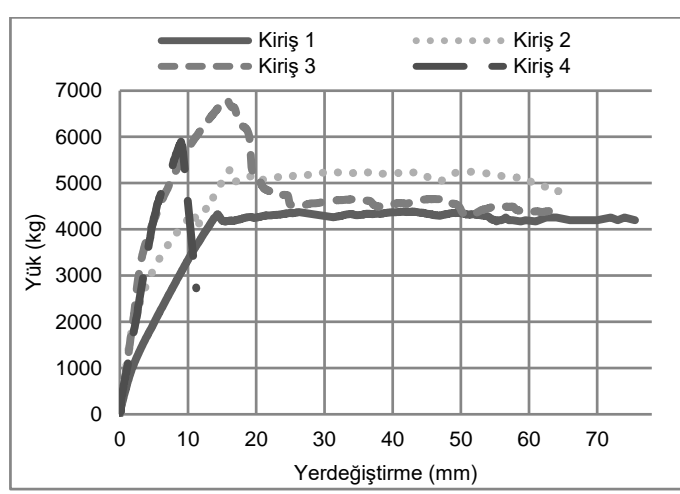

Şekil 12. UYPB ile güçlendirilmiş betonarme kirişlerin 4 yük-deplasman eğrileri
UYPB kalınlık değișiminin süneklik üzerindeki etkisini belirleyebilmek için deney elemanlarının deplasman süneklikleri belirlenmiş ve karşılaștırılmıștır. Bunun için öncelikle yük-düşey yerdeğiştirme ilişkileri kullanılarak akma yükü (Py), maksimum yerdeğiştirmeye karşılık gelen yük taşıma kapasitesi $(\mathrm{Pu})$, akma yerdeğiștirmesi $(\Delta y)$ ve maksimum yerdeğiștirme $(\Delta \mathrm{u})$ değerleri yük deplasman eğrisinden elde edilmiştir. Akma yerdeğiştirmesinin belirlenmesinde, ideal elasto-plastik davranıștaki akmayı esas alan azaltılmış rijitlik yaklaşımı kullanılmıştır [2830]. Bu yaklaşımda akma yerdeğiştirmesi $(\Delta y)$, kirişin maksimum yük taşıma kapasitesinin (Pmaks) \%75'ine karşıllı gelen nokta ile yükyerdeğiştirme eğrisinin başlangıç noktasını birleştiren bir doğrunun yardımıyla geometrik olarak belirlenmektedir (Șekil 13).



Şekil 13. Akma yer değiștirmesinin belirlenmesi [28]. 
DEU FMD 21(63), 1015-1026, 2019

Tablo 2. Kirișlerin eğilme testlerinden elde edilen karakteristik değerler

\begin{tabular}{|c|c|c|c|c|c|c|c|c|c|c|c|}
\hline $\begin{array}{c}\text { Kiriş } \\
\text { No }\end{array}$ & Pcr (kg) & $\begin{array}{c}\Delta_{\mathrm{cr}} \\
(\mathrm{mm})\end{array}$ & $P_{y}(\mathrm{~kg})$ & $\begin{array}{c}\Delta_{\mathrm{y}} \\
(\mathrm{mm})\end{array}$ & $P_{\text {maks }}(\mathrm{kg})$ & $\mathrm{Pu}(\mathrm{kg})$ & $\begin{array}{c}\Delta_{\mathrm{u}} \\
(\mathrm{mm})\end{array}$ & $\Delta_{\mathrm{u}} / \Delta_{\mathrm{y}}$ & $\begin{array}{c}\mathbf{P}_{\mathrm{u}} / \\
\mathbf{P}_{\text {maks }}\end{array}$ & E (kgmm) & $E_{n} / E_{1}$ \\
\hline Kiriş-1 & 1072,74 & 1,98 & 4406,19 & 14,31 & 4391,28 & 4278,73 & 75,53 & 5,28 & 0,97 & 269500,74 & 1,00 \\
\hline Kiriş-2 & 2350,45 & 2,74 & 5361,67 & 16,29 & 285,79 & 4947,66 & 65,22 & 4,00 & 0,94 & 315989,60 & 1,17 \\
\hline Kiriş-3 & 3785,19 & 3,91 & 6931,01 & 15,81 & 6931,01 & 4484,71 & 66,45 & 2,68 & 0,65 & 287243,80 & 1,07 \\
\hline Kiriş-4 & 5612,11 & 8,20 & 5132,42 & 7,08 & 5896,22 & 2723,71 & 11,21 & 1,58 & 0,46 & 39842,95 & 0,15 \\
\hline
\end{tabular}

Uygulanan lifli UYPB plaklar sayesinde kirişlerin önemli deplasman yapar hale geldikleri gözlenmiștir. Maksimum yerdeğiștirme ve akma yerdeğiştirmesi kullanılarak her bir kiriș için yerdeğiștirme sünekliğini ifade eden $(\Delta \mathrm{u} / \Delta \mathrm{y})$ değerleri Tablo 2'de sunulmuştur.

Farklı kalınlıkta UYPB plaka uygulanan kirişlerin süneklik değerleri ile referans kirișin süneklik değerleri Şekil 16'da karşılaştırılmıştır.



Şekil 14. UYPB kalınlıklarının yük taşıma kapasitesi üzerindeki etkisinin karșılaștırılması

Şekil 14'te UYPB plaka uygulaması ile dayanım açısından elde edilen katkı sunulmuștur. Kiriș 3 referans elemana göre taşıma kapasitesinde \%58 oranında artış sağlanmıştır. Bu değer çalıșmada elde edilen en büyük dayanım artışıdır. Kiriş 4 \%34'lük ve Kiriş 2 \%20'lik artış sağlamıştır.

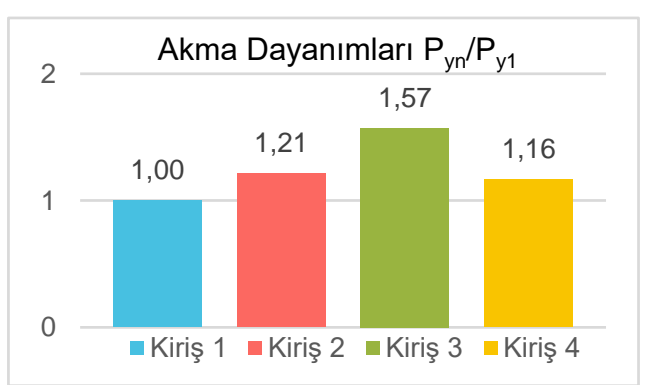

Şekil 15. UYPB kalınlıklarının akma dayanımlarının karşılaştırılması
Kiriş 2, Kiriş 3 ve Kiriş 4'ün akma dayanımları sırasıyla 1,21, 1,57 ve 1,16'dır. Elemanların plastik şekil değiștirmeye başladığı gerilme, akma dayanımıdır. UYPB plaka uygulaması betonarme kirișlerde yük tașıma kapasitesini arttırmış ve bu durum akma dayanımlarının da artmasına sebep olmuștur. UYPB plaka uygulaması ile referans elemana göre sırasıyla $\% 21, \quad \% 57$ ve $\% 16$ oranında artış meydana gelmiştir.

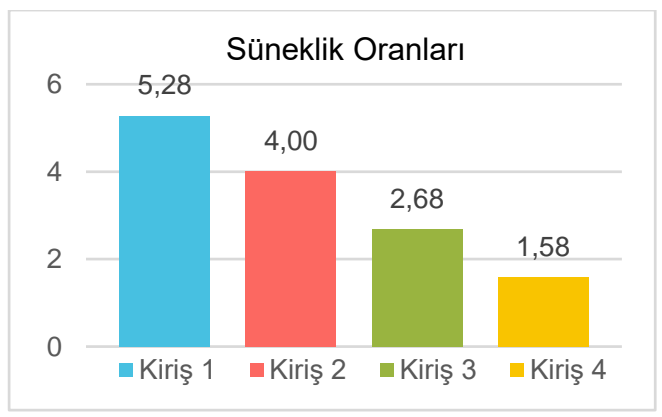

Sekil 16. UYPB kalınlıklarının süneklik üzerindeki etkisinin karșılaștırılması

Süneklik oranı; maksimum yerdeğiștirme değeri ile akma anına karşıllk gelen yerdeğiștirme değerinin oranlanması ile hesaplanmıștır. Referans kiriș olan Kiriș 1'in yaptığı en fazla yerdeğiştirme 75,53 mm ile deneysel programda da elde edilen en yüksek yer değiștirme değeridir. Buna uygun olarak süneklik oranı da 5,28 ile en yüksek süneklik oranıdır. Kiriș 2, Kiriș 3 ve Kiriș 4'ün deplasman süneklikleri sırasıyla 4,00, 2,68 ve 1,58 'dir. UYPB plaka uygulaması ile referans elemana göre $\% 76, \% 51$ ve $\% 30$ süneklik oranlarında azalma meydana gelmiştir. UYPB plaka betonarme kiriș ile birlikte çalıșarak yük taşıma kapasitesini arttırmış ve elemanlardaki kalınlık değişimi referans kirișe göre deplasman yapma kapasitelerinde azalmaya sebep olmuştur. Eğilme bölgesine yapıştırılan UYPB plakanın kalınlığının artmasıyla eleman daha rijit hale gelmiştir. Eğilme dayanımı yetersiz kirişe yapıştırılan bu plakalar, eğilme 
DEU FMD 21(63), 1015-1026, 2019

bölgesinde rijit bir levha gibi davranarak kirișin deplasman yapma kapasitesini azaltmıştır.

Süneklik genel olarak kırılmadan önce büyük plastik deformasyonlara uğrayabilme özelliği olarak tanımlanabilir. Ancak eğer deprem yükleri altında yapının taşıma kapasitesi yeterli değilse, süneklik miktarı bu enerjiyi sönümlemede yeterli olmayacaktır. Bu yapının dayanımını önemli ölçüde azaltan bir sorundur. Yapının deprem yükleri altında yeterli dayanıma sahip olabilmesi için hem sünek hem de taşıma kapasitesinin yeterli olması gereklidir. Deney elemanlarının donatı miktarı kesme dayanımına yeterli olacak şekilde tasarlandığı için akma dayanımına ulaşmaları beklenmektedir. $\mathrm{Bu}$ nedenle elemanların sünekliğini değerlendirirken sadece süneklik oranını karşılaştırmak yeterli olmayacaktır. Elemanların süneklik miktarın değerlendirirken süneklik oranına ek olarak enerji tüketimlerinin de değerlendirilmesi gerekmektedir.

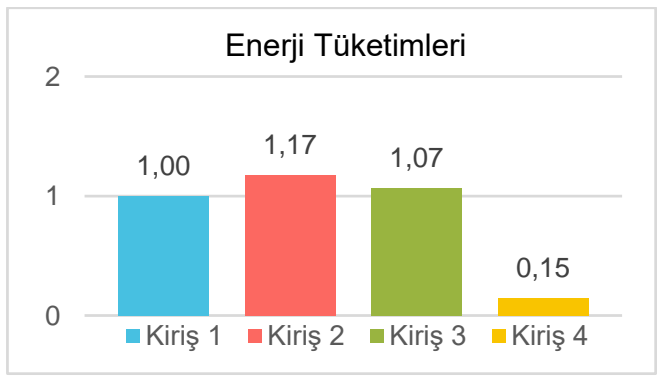

Şekil 17. UYPB kalınlıklarının enerji tüketimlerinin karşılaștırılması

Enerji tüketimi; deney elemanlarına uygulanan yük sonucunda çizilen yük-deplasman grafiklerinde oluşan kapalı alanın hesaplanmasıyla elde edilmiştir. Deney elemanlarının enerji tüketimleri göçmede hesaplanmıştır (Tablo 2). Deney elemanlarının birikimli enerji tüketim oranları Şekil 17'de sunulmuştur. Deney elemanlarında süneklik oranlarının azalmasına rağmen tașıma kapasiteleri arttığı için enerji yutma kapasiteleri de artmıştır. En fazla enerjiyi Kiriş 2 tüketmiştir. Kiriş 2; 310703,03 kgmm enerji tüketmiștir. Deney elemanı referans elemanından 1,17 kat fazla enerji tüketmiştir. Bunu 1,07 kat ile Kiriş 3 takip etmiștir. Deney programında en az enerjiyi Kiriş 4 tüketmiștir. Deney elemanı referans elemandan \%85 daha az enerji tüketmiştir. $70 \mathrm{~mm}$ kalınlığa sahip UYPB plaka betonarme kirişe yapıştırıldığında, deney elemanının deplasman yapma kapasitesini sınırlandırmıș bu nedenle eleman 39842,95 kgmm enerji tüketerek ani ve sesli olarak göçmüștür.

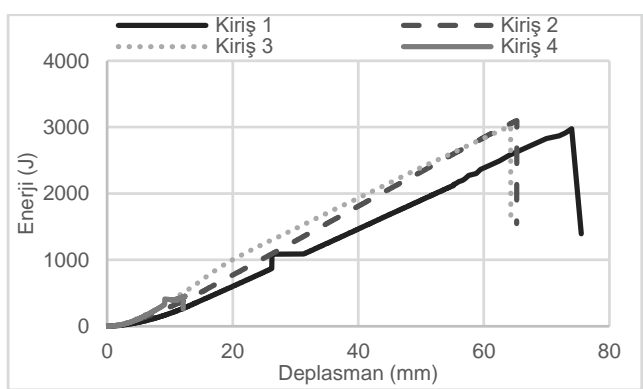

Șekil 18. UYPB kalınlıklarına göre enerjideplasman grafiği

Deney elemanlarının enerji-deplasman grafiği Şekil 18'de sunulmuştur. UYPB kalınlığının artmasıyla dayanımı artan deney elemanlarında bu artışa paralel bir enerji yutma kapasitesi artışı gözlenmemiştir. Kiriş 3 Kiriş 2'ye göre daha az enerji tüketmiștir. Kiriș 4'te UYPB plaka kalınlığının artmasıyla rijitlik artmakta ve elemanların deplasman yapma kapasiteleri azalmaktadır. Bu da elemanların enerji yutma kapasitelerini azaltmaktadır.

\section{Tartıșma ve Sonuç}

Bu çalıșmada farklı kalınlıklarda UYPB plakalar ile güçlendirilmiș betonarme kirișlerin dört noktalı eğilme testleri yapılmış ve kalınlık değișiminin eğilme davranışı üzerindeki etkileri incelenmiștir.

- \%3 oranında lifli UYPB ile eğilme dayanımı $40 \mathrm{MPa}$ ve basınç dayanımı $200 \mathrm{MPa}$ değerini aşan, optimum ișlenebilirlik sağlayan UYPB üretilmiştir.

- Gerçekleștirilen deneylerde UYPB plakalar eğilme dayanımı yetersiz kirişlere yapıştırılmıştır. Referans elemana göre tașıma kapasitesinde en düşük \%20, en yüksek \%58 oranında artış sağlanmıștır.

- Yerdeğiștirme sünekliğinde referans elemana göre en fazla $\% 80$ ve en az $\% 30$ oranında azalma meydana gelmiștir. Eğilme bölgesine yapıştırılan UYPB plakanın kalınlığının artmasıyla eleman daha rijit hale gelmiştir.

- Güçlendirilen kirişlerin yük taşıma kapasitesini arttırmıș ve bu durum 
DEU FMD 21(63), 1015-1026, 2019

akma dayanımlarının da artmasına sebep olmuştur. Referans elemana göre en fazla \%57 oranında artış sağlanmıștır. UYPB plaka kalınlığının artması ile akma dayanımı artmıştır.

- Enerji yutma kapasitesi en fazla olan eleman Kiriş 2'dir. Referans elemana göre \%17 oranında artıș sağlanmıștır. Kiriș 4'te UYPB plaka kalınlığının artması ile eleman daha rijit davranıs göstermiş ve akabinde UYPB plakanın beton yüzeyinden ayrılmasıla enerji yutma kapasitesinde azalma gözlenmiștir.

\section{Teșekkür}

114M2257 numaralı araştırma projesi ile çalışmaya destek olan Türkiye Bilimsel ve Teknolojik Araştırma Kurumu'na (TÜBİTAK) ve betonarme elemanların üretilmesi sürecinde sundukları destekler için Yeni Prefabrike Beton İnşaat San. Ve Tic. A.Ş.'ye teşekkür ederiz.

\section{Kaynakça}

[1] Tanarslan H.M., Alver N., Jahangiri R., Yalçınkaya Ç., Yazicı H. 2017. Flexural strengthening of RC beams using UHPFRC laminates: Bonding techniques and rebar addition. Construction and Building Materials DOI:155 (2017) 45-55

[2] Tanarslan H.M. 2017, Flexural strengthening of RC beams with prefabricated ultra high performance fibre reinforced concrete laminates, Engineering Structures DOI:151 (2017) 337-348

[3] Oehlers D.J., Reinforced concrete beams with plates glued to their soffits, J.Struct. Eng. 118 (1992) 2023-2038, http://dx.doi.org/10.1061/(ASCE)07339445(1992) 118:8(2023)

[4] Souza R.H.F., Appleton J., Flexural behaviour of strengthened reinforced concrete beams, Mater. $\begin{array}{llll}\text { Struct. } & 30 & \text { (1997) } & 154-159\end{array}$ http://dx.doi.org/10.1007/BF02486387.

[5] Yurdakul Ö., Avsar Ö., Strengthening of substandard reinforced concrete beamcolumn joints by external post-tension rods, Eng. Struct. 107 (2016) 9-22, http://dx.doi.org/10.1016/j.engstruct.2015.11.004.

[6] Altun F., An experimental study of the jacketed reinforced-concrete beams under bending, Constr. Build. Mater. 18 (2004) 611-618, http://dx.doi.org/10.1016/j.conbuildmat.2004.04.0 $\underline{05}$.

[7] Alhadid M.M.A., Youssef M.A., Analysis of reinforced concrete beams strengthened using concrete jackets, Eng. Struct. 132 (2017) 172-187, http://dx.doi.org/10.1016/j.engstruct.2016.11.014.

[8] Tetta Z.C. Koutas L.N., Bournas D.A., Textilereinforced mortar (TRM) versus fiber-reinforced polymers (FRP) in shear strengthening of concrete beams, Compos. Part B Eng. 77 (2015) 338-348, http://dx.doi.org/10.1016/j.compositesb.2015.03.0 55.

[9] Spadea G., Bencardino F., Swamy R.N., Structural behavior of composite rc beams with externally bonded CFRP, J. Compos. Constr. 2 (1998) 132-137, http://dx.doi.org/10.1061/(ASCE)10900268(1998) 2:3(132).

[10] Lamanna A.J., Bank L.C., Scott D.W., Flexural strengthening of reinforced concrete beams by mechanically attaching fiber-reinforced polymer strips, J. Compos. Constr. 8 (2004) 203-210, http://dx.doi.org/10.1061/(ASCE)10900268(2004) 8:3(203).

[11] Al-Saidy A.H., Saadatmanesh H., El-Gamal S., Al-Jabri K.S., Waris B.M., Structural behavior of corroded RC beams with/without stirrups repaired with CFRP sheets, Mater. Struct. 49 (2016) 3733-3747, http://dx.doi.org/10.1617/s11527-015-0751-y.

[12] Brühwiler, E. Rehabilitation and strengthening of concrete structures using Ultra-High Performance Fibre Reinforced Concrete, Concrete Repair, Rehabilitation and Retrofi tting III - Alexander et al. (eds), 2008.

[13] Kang S.-T., Ryu G.-S., The effect of steel-fiber contents on the compressive stress-strain relation of ultra high performance cementitious composites (UHPCC), J. Korea Concr. Inst. 23 (2011) 67-75, http://dx.doi.org/10.4334/JKCI.2011.23.1.067.

[14] Ghafari E., Costa H., Júlio E., RSM-based model to predict the performance of selfcompactingUHPC reinforced with hybrid steel micro-fibers, Constr. Build.Mater. $66 \quad$ (2014) 375-383, http://dx.doi.org/10.1016/j.conbuildmat.2014.05.0 64.

[15] Ghafari E., Arezoumandi M., Costa H., Júlio E., Influence of nano-silica addition in the durability of UHPC, Constr. Build. Mater. 94 (2015) 181-188, http://dx.doi.org/10.1016/j.conbuildmat.2015.07.0 09.

[16] Ghafari E., Costa H., Júlio E., Portugal A., Durães L., The effect of nanosilica addition on flowability, strength and transport properties of ultra high performance concrete, Mater. Des. 59 (2014) 1-9, http://dx.doi.org/10.1016/j.matdes.2014.02.051.

[17] Yalçınkaya Ç., Yazıcı H., Effects of ambient temperature and relative humidity on early-age shrinkage of UHPC with high-volume mineral admixtures, Constr. Build. Mater. 144 (2017) 252259 ,

http://dx.doi.org/10.1016/j.conbuildmat.2017.03.1 98.

[18] Mahmud G.H., Yang Z., Hassan A.M.T., Experimental and numerical studies of size effects of ultra high performance steel fibre reinforced concrete (UHPFRC) beams, Constr. Build. Mater. 48 (2013) 1027-1034,

http://dx.doi.org/10.1016/j.conbuildmat.2013.07.0 61.

[19] Hassan A.M.T., Mahmud G.H., Jones S.W., Whitford C., A new test method for investigating punching shear strength in ultra high performance fibre reinforced concrete (UHPFRC) slabs, Compos. Struct. $131 \quad$ (2015) 832-841, http://dx.doi.org/10.1016/j.compstruct.2015.06.04 4.

[20] Singh M., Sheikh A.H., Mohamed Ali M.S., Visintin P., Griffith M.C., Experimental and numerical study of the flexural behaviour of ultra-high performance fibre reinforced concrete beams, Constr. Build. Mater. $138 \quad$ (2017) 12-25, 
DEU FMD 21(63), 1015-1026, 2019

http://dx.doi.org/10.1016/j.conbuildmat.2017.02.0 02.

[21] Prem P.R., Murthy A.R., Acoustic emission and flexural behaviour of RC beams strengthened with UHPC overlay, Constr. Build. Mater. 123 (2016) 481-492,

http://dx.doi.org/10.1016/j.conbuildmat.2016.07.0 33.

[22] M.A. Al-Osta, M.N. Isa, M.H. Baluch, M.K. Rahman, Flexural behavior of reinforced concrete beams strengthened with ultra-high performance fiber reinforced concrete, Constr. Build. Mater. 134 (2017) 279-296, http://dx.doi.org/10.1016/j.conbuildmat.2016.12.0 94.

[23] Mohammed T.J., Abu Bakar B.H., Bunnori N.M., Strengthening of reinforced concrete beams subjected to torsion with UHPFC composites, Struct. Eng. Mech. $56 \quad$ (2015), http://dx.doi.org/10.12989/sem.2015.56.1.123

[24] Meda A., Mostosi S., Rinaldi Z., Riva P., Corroded RC columns repair and strengthening with high performance fiber reinforced concrete jacket, Mater. Struct. $\quad 49 \quad$ (2016) 1967-1978 http://dx.doi.org/10.1617/s11527-015-0627-1.

[25] Abdullah M.A.H., Mohd Zahid M.Z.A., Abu Bakar B.H., Nazri F.M., Ayob A., UHPFRC as repair material for fire-damaged reinforced concrete structure - a review, Appl. Mech. Mater. 802 (2015) 283-289, http://dx.doi.org/10.4028/ www.scientific.net/AMM.802.283.

[26] Yalçınkaya C.., Yazıcı H., Effect of early-age freezethaw exposure on the mechanical performance of self-compacting repair mortars, Sci. Eng. Compos.Mater. $23 \quad$ (2016) 335-344 http://dx.doi.org/10.1515/secm-2014-0006.

[27] Beglarigale A., Yalçınkaya Ç., Yigiter H., Yazıcı H., Flexural performance of SIFCON composites subjected to high temperature, Constr. Build. Mater $104 \quad$ (2016)99-108, http://dx.doi.org/10.1016/i.conbuildmat.2015.12.0 34.

[28] Park R. 1988. Ductility evaluation from laboratory and analytical testing. Proceedings of the 9th World Conference on Earthquake Engineering, Tokyo, Kyoto, 8, 605-616.

[29] Türker, K., Birol, T., Yavas, A. ve Hasgül, U., Ultra Yüksek Performanslı Lifli Beton İçeren Kirislerde Etkin Çelik Lif Tipi İncelemesi, Afyon Kocatepe Üniversitesi Fen ve Mühendislik Bilimleri Dergisi, 16, 776-785, (2016).

[30] Türker, K., Birol, T., Yavas, A., Hasgül, U. ve Yazıcı H., Ultra Yüksek Performanslı Lifli Beton ile Üretilmis Betonarme Kirislerin Eğilme Davranışı, Teknik Dergi, 2019 8777-8801, Yazı 523, DOI:10.18400/tekderg.287116.

[31] Taşdemir, M. A. ve Bayramov, F. Yerlikaya M. Geleneksel ve Yüksek Performanslı Çelik Donatılı Betonlar, TMH - Türkiye Mühendislik Haberleri Sayı:426 - 2003/4 